\title{
Network Approaches to Substance Use and HIV/Hepatitis C Risk among Homeless Youth and Adult Women in the United States: A Review
}

\author{
Kirk Dombrowski1, Kelley Sittner², Devan Crawford³, Melissa Welch-Lazoritz³, Patrick Habecker¹, \\ Bilal Khan'
}

${ }^{1}$ Department of Sociology, University of Nebraska-Lincoln, Lincoln, USA

${ }^{2}$ Department of Sociology, Oklahoma State University, Stillwater, USA

${ }^{3}$ REACH Lab, University of Nebraska-Lincoln, Lincoln, USA

Email: kdombrowski2@unl.edu

How to cite this paper: Dombrowski, K., Sittner, K., Crawford, D., Welch-Lazoritz, M., Habecker, P. and Khan, B. (2016) Network Approaches to Substance Use and HIV/ Hepatitis C Risk among Homeless Youth and Adult Women in the United States: A Review. Health, 8, 1143-1165.

http://dx.doi.org/10.4236/health.2016.812119

Received: July 20, 2016

Accepted: August 23, 2016

Published: August 26, 2016

Copyright $\odot 2016$ by authors and Scientific Research Publishing Inc. This work is licensed under the Creative Commons Attribution International License (CC BY 4.0).

http://creativecommons.org/licenses/by/4.0/

\section{(c) (i) Open Access}

\begin{abstract}
During the United States economic recession of 2008-2011, the number of homeless and unstably housed people in the United States increased considerably. Homeless adult women and unaccompanied homeless youth make up the most marginal segments of this population. Because homeless individuals are a hard to reach population, research into these marginal groups has traditionally been a challenge for researchers interested in substance abuse and mental health. Network analysis techniques and research strategies offer means for dealing with traditional challenges such as missing sampling frames, variation in definitions of homelessness and study inclusion criteria, and enumeration/population estimation procedures. This review focuses on the need for, and recent steps toward, solutions to these problems that involve network science strategies for data collection and analysis. Research from a range of fields is reviewed and organized according to a new stress process framework aimed at understanding how homeless status interacts with issues related to substance abuse and mental health. Three types of network innovation are discussed: network scale-up methods, a network ecology approach to social resources, and the integration of network variables into the proposed stress process model of homeless substance abuse and mental health. By employing network methods and integrating these methods into existing models, research on homeless and unstably housed women and unaccompanied young people can address existing research challenges and promote more effective intervention and care programs.
\end{abstract}




\section{Keywords}

Network Science, Homeless Women, Homeless Youth, Stress Process Models, Network Ecology, Racial/Ethnic Health Disparities

\section{Introduction}

During the United States economic recession of 2008-2011, poverty levels increased substantially, as did the number of "doubled-up" households, foreclosures, those on welfare and homeless adults and children [1]. In addition to economic consequences, the recession also had negative effects on people's health and mental health, some of which have been documented in national and regional sources [1] [2]. A handful of studies have examined the extent to which the economic consequences suffered during the Great Recession led to alcohol problems. For example, according to Burgard, alcohol consumption increased as did binge drinking and alcohol dependence [1]. Little specific attention, however, has been given to the substance use and mental health needs of homeless populations and those made homeless by the economic downturn.

Homeless and unstably housed youth [HUHY] make up one of the most vulnerable populations in the U.S. They often are victims of caretaker physical and sexual abuse [3]-[5], family disorganization [3] [6], sexual exploitation [7]-[9], hunger [10] [11], and physical and sexual assault when on the streets [3] [12] [13]. Sexual behaviors, drug use, and subsistence behaviors make them among the most susceptible to sexually transmitted infections (STIs) such as HIV/AIDS [14]-[17] and hepatitis [18]-[20], most HUHY lack conventional social support and adult mentorship [21] [22]. These combined risk factors take an enormous psychological and developmental toll. Over time, conventional opportunities diminish and the consequences of street life accumulate. This "cumulative continuity" [23] can result in a lifetime of marginality characterized by antisocial behaviors [24]-[26], involvement in the criminal justice system [27]-[29], drug abuse and dependency [30] [31], economic disadvantage [32], health problems [33], and adult psychiatric disorders [13]. Although there have been numerous studies of homeless youth, there has never been a comprehensive national study of the spectrum of HUHY that comprise this complex subpopulation.

Similarly, homeless adult [HA] women remain a significantly understudied population. Perhaps because women make up a lower percentage of homeless adults, studies of HA women are relatively scarce in comparison to both general studies of HA and studies of male HA. What few studies exist of specifically female HA are characterized by small sample sizes and restricted to a single location in predominantly large coastal cities. There are few regional or longitudinal studies of HA women in the United States. Of the few studies of female HA, a significant number focus only on specific subpopulations of HA women (i.e., HIV+ samples, in-treatment/clinical samples). Although HA women are one of the fastest growing segments of the homeless population in the United States [34], they remain an understudied group [35]. What findings exist suggest 
HA women are an extremely vulnerable population, demonstrating comparable or higher rates of substance use and mental health needs as HA men. Similar results are obtained when HA women are compared to housed women [36] [37]. The few welldesigned, large sample studies that included subsamples of homeless women are now more than a decade old [38] and existing studies do not include the entire spectrum of homeless women. Research to address this problem at regional levels and across a large US region is needed to characterize this rapidly changing population.

\section{Network Approaches to Homeless Population Estimation}

Among the more important questions confronting policy makers concerned with hardto-reach and hidden populations is the size of the population itself [39] [40]. Though fluid and often dependent on definitions of homelessness, such data are nevertheless critical to effective programing and budgeting at the national and local levels [41]-[43]. Unfortunately, as Lee et al. point out, hard-to-reach populations are, by definition, equally hard-to-enumerate [44] (see also Marpsat and Razafindrastsima [45]).

Understanding the size and distribution of the full spectrum of HUHY and HA women housing needs is critical. The most recent estimates of the number HUHY range from 380,000 [46] to $1,500,000$ [44]. The wide range of estimates is caused by differences in the definition of homelessness: different housing statuses [sheltered and unsheltered], idiosyncratic estimation designs, differing age criteria, and/or a focus on specific identity groups [47] [48]. Moreover, many of these estimates fail to recognize that homelessness is not a steady state [49]. HUHY are constantly shifting between short-term housing, shelters, living in institutional settings [50] (e.g., foster care and serial fosterage, group homes, and post-incarceration settings), and episodes of street homelessness. The link between the housing statuses of young people [51] and differences in sexual identity [52], gender [53], employment [54], drug use [55]-[57], mental health [13], criminal justice involvement [28] [58], victimization [59], and family support [6] are well recognized. Yet each of these axes provides unique challenges to programs aimed at reducing harm, risk, and victimization among the population. Only by knowing the extent and needs of each of these groups can we hope to sufficiently address the risk of the population as a whole. This is particularly true for $\mathrm{HIV} / \mathrm{HepC}$ policy, as the social conditions of HUHY present barriers to testing, awareness building, and outreach, while those involved remain at substantial risk [15] [60]-[62]. Taken singly, these problems represent significant program challenges; together they represent a crisis for an entire population.

Beyond housing status, there is consensus that HUHY tend to cluster by identity and/or subsistence strategies, [63], further fracturing service delivery and outreach. Much of the current research, however, focuses on a single identity cluster (e.g., LGBT, travelers, sexually exploited children, gangs), leaving the relationships between these clusters largely unknown. Movement between clusters and the transfer of risk behaviors from one to another are also clear, resulting in a situation best described as a "total risk network" [64] [65]. Identity specific research, in combination with small, non-repres- 
entative samples (e.g., a single shelter, or clients of a single program), neglects the web of connections between risk groups. This results in a loss of critical epidemiological information and misleading estimates of the proportions and characteristics of HUHY by identity, which can exacerbate service shortages and result in less than optimum service delivery plans.

For all these reasons, reaching the full spectrum of HUHY is crucial, and delays in doing so are costly in both personal and social terms. There is plentiful evidence that the number and length of homeless episodes are central factors in risk for victimization and stress [66]. There is also evidence that the consequences for mental health, substance abuse, and physical health are amplified by time on the streets and repeated victimization [67] [68]. All of these factors are associated with elevated levels of HIV/ HepC exposure, creating a feedback loop where behavioral risk is amplified at each successive episode of housing loss.

In the 1990s, "point-in-time" estimation [48] [69] and "plant/capture" correction procedures [70] were developed as advances over conventional homeless census techniques [71]-[73] and both were used in a number of US cities [47] [74] [75] (recently, see Bezerra et al. [76]). Yet both point-in-time and plant/capture are dependent on the existence of total census operations for their effectiveness. The use of social network techniques for population estimation from more limited samples represents a new direction in counting hard-to-enumerate groups [77]-[80].

The most notable of the new network techniques is referred to as the "network scale-up method" (NSUM). This method has been used in research on hard-to-enumerate populations, including HIV prevalence for out of treatment populations and numbers of injection drug users [81]-[84]. Though questions have been raised in comparative trials about discrepancies between NSUM and other estimation methods [85], the concept of network-based sampling has secured an important place among those who do research with hard-to-enumerate populations, including the considerable attention gained by respondent driven sampling (RDS) techniques [86]-[89]. More recently, researchers in New York have combined ideas drawn from network scale-up methods and conventional capture/recapture techniques. These techniques were used in two prior NIJ funded studies to estimate the number of commercially sexually exploited children [90] and methamphetamine users [91]. In more recent work, these techniques were expanded to include confidence intervals and error estimation [80]. Such work holds promise for use in other locations.

\section{Peer and Network Influences on HIV Risk among Homeless and Unstably Housed Youth}

As Ennett et al. noted more than a decade ago [92], peer networks among young people clearly demonstrate both risk-enhancing and risk-decreasing properties that influence substance abuse and unsafe sexual behavior. More recently, researchers have framed this question as the issue of prosocial versus problematic peers, and tied it directly to HIV incidence among homeless adolescents. Rice et al.'s [93] study of young people in 
unstable housing in Los Angeles found that the number of prosocial peers had demonstrable effects on the likelihood of HIV risk over time, building on earlier work that showed the effect of these same factors on drug choice/use [94] (see also Bousman [95] for similar results for homeless youth from San Diego, and similar network findings by Kipke et al. [96]). Ferguson found that for highly mobile or "transient" homeless youth, being dependent on peers, as opposed to family, was closely associated with participation in street-survival behaviors, including survival sex [97] (see Tyler [98] and Um [99] for drug use and overall risk).

Elsewhere [100], some of these same data were used to show that peer network composition for homeless adolescents changed over time, away from "prosocial" peers and toward those network connections that increased HIV risk. The latter is important, as it shows a changing trajectory of HIV risk that is activated through network mechanisms, which in turn corresponds directly to time spent on the street. Indeed, it is possible that one central and often ignored mechanism for the cumulative effect of "time on the street" can be found in the changing composition of individual social networks. Evidence for this is emerging. Working in Los Angeles, Martino et al. [101] found that rates of risk for HIV were higher among "traveler" youth who demonstrate long-term and long-distance migration patterns. Here, differences in risk correlated with differences in social network composition, as over time HUHY moved away from "conventional individuals and institutions" and toward others like themselves [102].

Others have examined the link between drug use and sex-based risk among HUHY [103] [104]. In work by Weber et al. [105], sexual risk among homeless youth was found to be influenced by the combination of partnership choices and drug use (both in kind and frequency), highlighting a theme that recurs in later research: sexual risk and risk of substance abuse are closely interrelated [65] [106] [107]. These findings echo results of research by Dombrowski et al. for non-street-based users of methamphetamine in New York City [91], as well as for adolescents engaged in commercial sex work [90]. Here, peer and network influences on sexual risk are important considerations. Among 249 respondents, $46 \%$ of girls, $44 \%$ of boys, and $68 \%$ of transgendered youth said that they were recruited into the commercial sex economy by "friends", rather than by potential customers, market facilitators (pimps/“boyfriends") or family members (p. 46). The report notes:

CSEC [commercially sexually exploited children] peer groups were not only vital to youth's entry into the market, but also to their ability to engage the market and their decision to remain in "the life". Some of their networks were quite extensive, and over one quarter of the teens (27\%) claimed to know 20 or more CSEC youth, an additional $20 \%$ of the youth said that they knew between 10 and 20 other CSEC youth... There was a widespread ethos among CSEC youth of helping each other out, even if they did not know each other very well, and this orientation extended into the market and beyond... "We recommend customers to one another and help each other out. 'Cause we all in the same predicament, so why not...if I could look out, I'm gonna look out” (p. 59).

Homelessness played a critical role in motivating participation. The majority of study 
participants were living in an unstable situation: $32 \%$ of the sample for this study described their situation as "living in the street" with an additional $44 \%$ of girls saying they lived "outside a family home" [90].

With the recognition that network peers influence risk has come the realization that peer and network influences may also affect service delivery and positive social support [108] [109]. Recent work by Rice et al. and Chew Ng et al. emphasize the potential of network ties to increase shelter use [110] and reduce substance use [111]. As these authors note, social ties can be used to facilitate peer-based interventions, yet to do so, we must know more about the overall network structures that link homeless and unstably housed young people to one another [112]. This includes ties within and across identity groups, subsistence clusters, and across the full range of housing situations. Such data are rare in a single network study. Full network topologies (network sociograms that go beyond ego networks to display the full set of connections among a group) are nearly non-existent among HUHY. Nor do we know much about the connections between clusters, or the structure of the relationship between HUHY and their non-homeless peers.

To make matters worse, most studies of homeless youth have not provided adequate comparison groups among those marginally housed and those currently experiencing an episode of homelessness who may be co-participants in many of the same activities or behaviors. As noted above, the relationship between HIV/HepC risk (via drug use and commercial/exchange sex) and the range of housing statuses remains murky; while it may be well known in some places [113] [114], it is largely unknown in others.

\section{Stress Processes among HA Women}

Both stress and substance abuse/dependence disorders (SAD) are disproportionately high among homeless adult populations. Available evidence indicates that homeless adults experience significantly more stressors than other populations, including lowincome housed adults [115]. In part, this is attributable to contemporaneous stressors: the fact that homelessness itself is stressful, whether due to the events of becoming homeless or to the enduring, chronic strains associated with being on the street. Yet homelessness itself is frequently the result of prior stressors, such as childhood abuse, unemployment, intimate partner violence, and past homelessness.

Homeless women encounter more stressors and strains on average than housed women. They are more likely to be victims of violence [116] and sexual assault [117], more likely to have a current and lifetime mental disorder, and to be unemployed or under employed. A large proportion of HA women may be accompanied by children, yet other HA women do not have physical custody of their children [118] [119]. Both circumstances may operate as significant sources of stress. HA women, by virtue of being homeless and being negatively regarded by the public, may experience discrimination when seeking services or in their daily lives [120]. Their gender may also place them at risk for discrimination in wage discrepancies and employment [121].

The same bi-directional causality can be seen in the area of substance use/abuse 
among homeless adults. In general, substance use is one response to stress [122] [123], and has also been found to exacerbate stress [124]. Among HA women, rates of substance use disorders vary between $30 \%$ and 55\% [125], and rates of binge drinking and hard drug use are also quite high [126]. Chronic or ongoing stressors increase or exacerbate existing substance use problems. In Tucker et al.'s study [116] comparing sheltered and housed women in Los Angeles, those living in a shelter were more likely to have experienced violence, which propelled them into homelessness, and were more likely to report an increase in alcohol/drug use in response to the violence. Furthermore, the presence of mental disorder may generate additional mental health problems and stressful experiences [127] [128], and thereby affect the development or persistence of SAD.

These factors can be captured under a single model that combines a classic stress process model [129] [130] with Whitbeck et al's risk amplification model [67] to consider both the bi-directional nature of the stress-substance use relationship and the buffering role of social network supports and access, as shown in Figure 1. The model links 5 core concepts in a complex model of directed and bi-directed causality. Here the major elements identified by prior researchers of homeless adults and HA women are represented as boxes: Prior Stressors, Contemporaneous Stressors, Substance Abuse and Dependence, Social Support and Exchange Networks, and a range of Homeless Outcomes that are at once contemporaneous stressors, and the behaviors/strategies most often linked to the perpetuation of homelessness (reliance on sex work survival strategies, CJS involvement, deviant subsistence strategies, and related outcomes). These 5 core concepts are related by a series of causal and bi-directional links (A through I) that predict homeless outcomes.

Thus, for example, it could be that HA women who engage in higher levels of substance use and/or have substance abuse and dependence disorders often experience more stressors (path B), whose manifestation is perpetuated by their substance abuse/

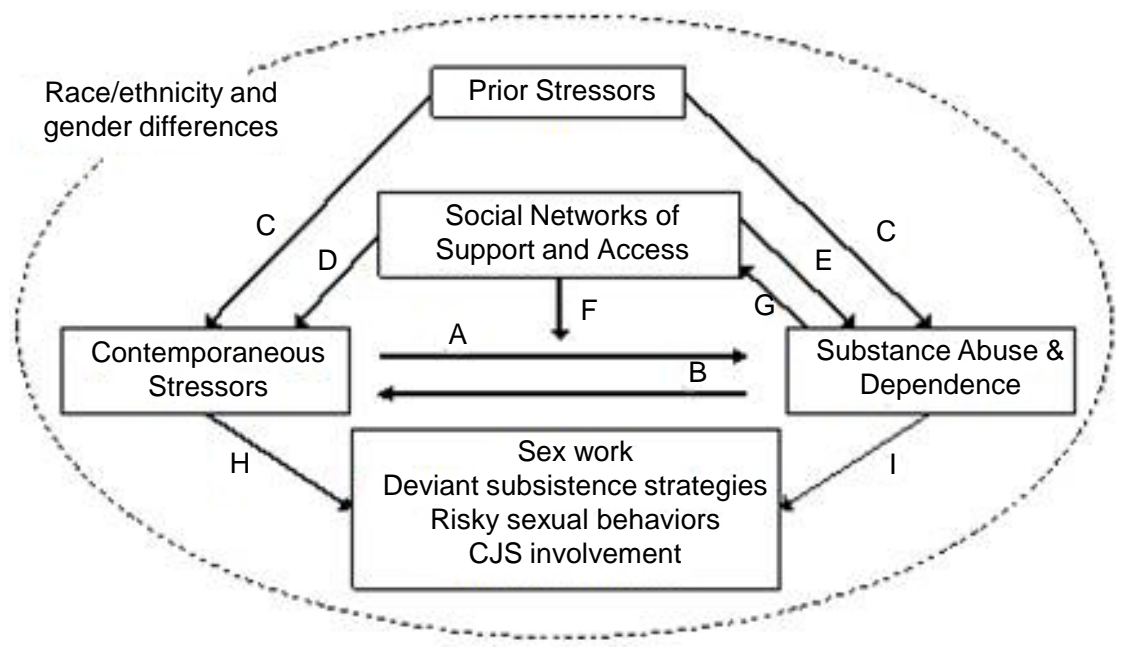

Figure 1. A stress process model for substance abuse and mental health among homeless populations. 
dependence (path A). These together can perpetuate homeless outcomes (paths $\mathrm{H}$ and I; such as missed counseling appointments) that later contribute to failed efforts to exit homelessness though failures of program compliance. Examples of such simultaneous cause/effect/cause relationships are well documented in the literature: for example, being under the influence of drugs or alcohol places homeless people on the street at higher risk of being victimized [131], which in turn acts as a stressor for mental health issues, which can in turn trigger continued reliance on substance use.

This model also takes into account the role of prior stressors. Women's experiences prior to becoming homeless, including during childhood, are often predictive of both later homelessness and SAD (path C). Stressors in childhood such as child maltreatment have been associated with risk for adult alcohol use disorders [132]. Compared to housed women, rates of childhood abuse and neglect are higher in samples of HA women [133]-[135]. It is estimated that $19 \%$ to $63 \%$ of the homeless women in prior studies had been abused or neglected as children [136] [137]. In adulthood, rates of intimate partner violence are also considerably higher among HA women than housed women [35] [116] [138]. Additionally, homeless adults are more likely to have family histories of homelessness or housing instability [139]. These prior stressors have direct effects on current stressors, contributing to their proliferation [140], as well as on current substance use problems (path C). For instance, childhood abuse is positively associated with later mental health problems among homeless youth [141]. Furthermore, prior stressors may be associated with SAD via their effects on current stressors. Among HA women, childhood abuse has been associated with chronic homelessness and substance use problems in part because of its effect on later physical abuse [30].

\section{Network Approaches to a Stress Process Model of HA Women, as a Means to Address Racial/Ethnic Disparities}

Research on the topic of homeless women and substance use/abuse is timely given recent economic changes that have increased the homeless population in suburban and rural areas. Nationally, between 2007 and 2010, the number of homeless families is estimated to have increased by $20 \%$ and the number of those families using shelters increased by 57\% [142]. A recent report by the National Coalition for the Homeless indicates that the subprime mortgage crisis especially affected lower-income families and single parent families [143]. Often these families are female-headed householdsshowing that gender differences extend beyond individual vulnerabilities to impact homeless children as well [144]. Many of the affected households continue to live in unstable housing situations, indicating that for those on the bottom, the housing crisis is not over. For individuals having gone through the process of home loss and foreclosure, the health repercussions are just now being understood [145]-[147].

Apparent ethnic/racial differences among HA women may mask more salient social differences related to broad political economic changes, particularly in the aftermath of the social transformations that have taken place in the last several years. No current or previous study has examined how racial/ethnic outcomes may be related to differing 
levels of social capital and social network access in a rapidly changing rural political economy. Shelter populations in mid-size Central US cities now contain women from longstanding, historically urban African American populations, newly arrived white women displaced by changes in agricultural economies, Hispanic women who have immigrated more recently to work in the emerging rural economy, and Native American women who move between reservation and urban margins. Together, they represent a significant departure from past populations. Such personal historical differences necessarily provide different levels of social support that significantly impact both the ability to transcend homeless and deal with substance use/abuse issues.

In the Central US, the housing crisis may have both masked and accelerated ongoing rural social changes [148] [149]. Much of this transformation has been tied to changes in the meat packing industry that have attracted considerable migration from Central America [150]-[152]. Yet other deep structural changes have emerged recently as well, including differences in gendered employment [153]-[155], uneven and short-lived patterns of return migration [156] [157], differential impact of age [158] and education [159] on migration, and related general patterns of rural economic well-being [160][162]. One possible explanation is that these changes lie behind surface statistics documenting racial/ethnic health disparities among homeless women in the region. While little specific research has focused on this topic in the region, racial and ethnic health disparities among homeless women are well known [163]-[165].

In this view, racial and ethnic differences in homeless trajectories (and their related health outcomes) would be seen as closely related to differences in the social networks of support and influence, which themselves are products of markedly distinct roles that women of different ethnic and racial groups play in the emerging rural economy of the Central US. For white women in the region, rural economic decline has, for some, meant a descent into poverty and resulting strained family ties, internal migration, and new forms of welfare dependency. In contrast, Hispanic migrant women, many of whom lack legal documentation, can draw on little support when domestic or economic changes overwhelm personal resources. African American women in the region are primarily urban, and many are able to retain social networks despite tenuous economic status (in contrast, for example, to migrant Hispanic women). And Native American women often move in and out of social networks as conditions in home reservation communities prompt circular patterns of migration into and out of regional urban areas.

In each case, individual social networks reflect these historical differences, and are reflected in individual histories of housing instability and homelessness. If different groups, seemingly identifiable by racial or ethnic background, draw on very different networks of support, then their differential paths out of homelessness would likely be very different. To the extent that homelessness itself is a recognized vector for both substance abuse and health deterioration, the ability to tailor programs to specific needs (toward and from desired and undesired influences) represents an important step forward in our ability to meet the needs of what, on the surface, may seem a uniformly 
needy population.

Network considerations can be added as mediators and moderators of the new stress process model shown in Figure 1. Considerable evidence exists for this approach. Prior research has found that negative social supports and coping strategies promote drug use or drug problems, whereas positive coping and social support reduce those same problems [34]. Throughout the US, HA women have been found to lack strong positive social support systems [133] [166], which are integral to obtaining and maintaining stable housing. Social networks remain an important and understudied aspect of homeless women's experience, that may have direct effects (path F) as well as moderating and mediating effects on stress exposure and substance use (paths D and E). First, these networks can reduce or ameliorate stressors associated with being homeless by providing important avenues of emotional and instrumental support (path D). Second, a key factor in preventing and recovering from SAD is having access to effective social support networks (path E). Conversely, some social networks may facilitate or exacerbate both the stressors associated with homelessness and SAD if antisocial, abusive, or substance using peers and family members constitute a woman's social network. Third, social networks serve as a key moderator of the stress/SAD association (path F), whereby women who experience stressors associated with being homeless may be more likely to reduce substance use or seek treatment if they have supportive networks, compared to women with more stressors but weak social supports. Finally, social networks themselves may be influenced by the SAD of women, including the composition of the network (i.e., selecting substance using network members) as well as by damaging relationships with prosocial members (path G). These networks then may be an important mediator in the substance use-to-stress association.

At stake in such a network-enabled model is the ability to better predict homeless outcomes. Being homeless often necessitates adaptive behaviors as survival mechanisms, including sex work and deviant subsistence strategies (path H). SAD may also facilitate negative behaviors associated with abuse/addiction, such as risky sexual behaviors and deviant subsistence strategies (path I). In a study of homeless young people in four cities, being unemployed and having drug problems increased the odds of engaging in risky survival strategies [97]. Furthermore, both homelessness and SAD are associated with involvement in the criminal justice system, as many of the behaviors associated with them place homeless women at risk for arrest and imprisonment. It is estimated that $20 \%$ to $52 \%$ of women who have been homeless also have a history of criminal justice system involvement [38] [167] [168].

Contextualizing this entire model is the larger question of ethnic/racial differences in homeless outcomes (dashed circle). These differences may appear in any of the relationships in the model. For instance, distributions of stress and adversity may be highest among African Americans [122], which may partially account of the disproportionately higher numbers of African American homeless women in the cities we will study. Substance abuse and dependence also varies by racial/ethnic status, with higher rates among American Indian and white women and lower rates among African American women in general population studies [169]. Negative outcomes such as CJS in- 
volvement may also be higher for racial/ethnic minority women, compared to white women. Importantly, it is very likely that access to supportive social networks will also differ across racial/ethnic groups [170], which also impacts both homelessness and SAD. In sum, race/ethnicity is an important determinate of both homeless experiences and SAD.

There are clear payoffs from defining network actors and ties more broadly: chiefly, in this model people are not only seen as sources of resources, they are also seen as sources of resource competition [171]. Given the limited resources available to HA women, individuals in the same vicinity, doing the same things, are potential competitors for the same goods and services. For example, a street corner cannot support a large number of people pan-handling in the same location. In this view, subsistence and other survival strategies, like shelter beds, exist in a finite ecology of limited resources [171]-[173]. This competition is directly related to both flows of resources and sources of stress for HA women (see, for example, the link between scarcity and stress by Ensel and Lin [174]). In short, by thinking in terms of competition, and not just resources, researchers can test specific hypotheses about behavior, substance use, and mental health changes. Future research should examine these networks at multiple instances to see how patterns of exchange and network ties evolve over time [175]-[177] and how stress and competitive pressure affects mental health outcomes and behaviors over time [178]. At a macro level, we should consider how the entire system of exchange changes over time, as well as how the connections between organizations (defined by serving the same population) evolve over time.

\section{Network Approaches to a Stress Process Model of HA Women, as a Means to Address Racial/Ethnic Disparities}

This review argues that network techniques can play an important role in understanding substance abuse and HIV/hepatitis risk among two segments of the US homeless population: homeless adult women and homeless and unstably housed youth. In the last three decades, the use of network techniques has grown significantly public health research. We have discussed evidence that supports the greater use of network data collection and analysis in three areas: 1) population enumeration of the homeless and unstably housed, especially homeless youth (using combined network scale-up and capture-recapture methods), 2) a sociometric approach to homeless adult resource use and competition (using a network ecology approach), and 3) the integration of network factors into existing stress process models aimed at understanding substance abuse and mental health interactions (using a network-enhanced stress process model shown above). Together these elements hold out promise for greater integration of existing research findings, which in turn can help intervention planners to more successfully meet the needs of a group that has grown in both size and complexity over the last decade.

\section{Acknowledgements}

This work was supported by the NIH National Institute on Drug Abuse of the National 
Institutes of Health (grant number R01DA037117) and the NIH National Institute for General Medical Sciences (grant number R01GM118427). The content is solely the responsibility of the authors and does not necessarily represent the official views of the National Institutes of Health.

\section{References}

[1] Burgard, S.A., Ailshire, J.A. and Kalousova, L. (2013) The Great Recession and Health People, Populations, and Disparities. Annals of the American Academy of Political and Social Science, 650, 194-213. http://dx.doi.org/10.1177/0002716213500212

[2] Mulia, N., Zemore, S.E., Murphy, R., Liu, H. and Catalano, R. (2014) Economic Loss and Alcohol Consumption and Problems during the 2008 to 2009 US Recession. Alcoholism Clinical and Experimental Research, 38, 1026-1034. http://dx.doi.org/10.1111/acer.12301

[3] Whitbeck, L.B. and Hoyt, D.R. (1999) Nowhere to Grow: Homeless and Runaway Adolescents and Their Families. Transaction Books, Piscataway.

[4] Cauce, A.M., Paradise, M., Ginzler, J.A., Embry, L., Morgan, C.J., Lohr, Y., et al. (2000) The Characteristics and Mental Health of Homeless Adolescents Age and Gender Differences. Journal of Emotional and Behavioral Disorders, 8, 230-239. http://dx.doi.org/10.1177/106342660000800403

[5] Powers, J.L., Eckenrode, J. and Jaklitsch, B. (1990) Maltreatment among Runaway and Homeless Youth. Child Abuse \& Neglect, 14, 87-98. http://dx.doi.org/10.1016/0145-2134(90)90084-7

[6] Tyler, K.A. (2006) A Qualitative Study of Early Family Histories and Transitions of Homeless Youth. Journal of Interpersonal Violence, 21, 1385-1393. http://dx.doi.org/10.1177/0886260506291650

[7] Widom, C.S. and Kuhns, J.B. (1996) Childhood Victimization and Subsequent Risk for Promiscuity, Prostitution, and Teenage Pregnancy: A Prospective Study. American Journal of Public Health, 86, 1607-1612. http://dx.doi.org/10.2105/AJPH.86.11.1607

[8] Hagan, J. and McCarthy, B. (1998) Mean Streets: Youth Crime and Homelessness. Cambridge University Press, Cambridge.

[9] Tyler, K.A. and Johnson, K.A. (2006) Trading Sex: Voluntary or Coerced? The Experiences of Homeless Youth. Journal of Sex Research, 43, 208-216. http://dx.doi.org/10.1080/00224490609552319

[10] Whitbeck, L.B., Chen, X. and Johnson, K.D. (2006) Food Insecurity among Homeless and Runaway Adolescents. Public Health Nutrition, 9, 47-52. http://dx.doi.org/10.1079/PHN2005764

[11] Tarasuk, V., Dachner, N., Poland, B. and Gaetz, S. (2009) Food Deprivation Is Integral to the "Hand to Mouth" Existence of Homeless Youths in Toronto. Public Health Nutrition, 12, 1437-1442. http://dx.doi.org/10.1017/S1368980008004291

[12] Kipke, M.D., Simon, T.R., Montgomery, S.B., Unger, J.B. and Iversen, E.F. (1997) Homeless Youth and Their Exposure to and Involvement in Violence While Living on the Streets. Journal of Adolescent Health, 20, 360-367. http://dx.doi.org/10.1016/S1054-139X(97)00037-2

[13] Whitbeck, L.B. (2009) Mental Health and Emerging Adulthood among Homeless Young People. Psychology Press, New York, 312 p.

[14] Marshall, B.D.L., Shannon, K., Kerr, T., Zhang, R. and Wood, E. (2010) Survival Sex Work and Increased HIV Risk among Sexual Minority Street-Involved Youth. Journal of Acquired Immune Deficiency Syndromes, 53, 661-664. 
[15] Marshall, B.D.L., Kerr, T., Qi, J., Montaner, J.S.G. and Wood, E. (2010) Public Injecting and HIV Risk Behaviour among Street-Involved Youth. Drug and Alcohol Dependence, 110, 254-258. http://dx.doi.org/10.1016/j.drugalcdep.2010.01.022

[16] Gangamma, R., Slesnick, N., Toviessi, P. and Serovich, J. (2008) Comparison of HIV Risks among Gay, Lesbian, Bisexual and Heterosexual Homeless Youth. Journal of Youth and Adolescence, 37, 456-464. http://dx.doi.org/10.1007/s10964-007-9171-9

[17] Roy, É., Robert, M., Vaillancourt, É., Boivin, J.-F., Vandermeerschen, J. and Martin, I. (2011) Residential Trajectory and HIV High-Risk Behaviors among Montréal Street Youth-A Reciprocal Relationship. Journal of Urban Health, 88, 767-778. http://dx.doi.org/10.1007/s11524-011-9574-5

[18] Walls, N.E. and Bell, S. (2011) Correlates of Engaging in Survival Sex among Homeless Youth and Young Adults. Journal of Sex Research, 48, 423-436. http://dx.doi.org/10.1080/00224499.2010.501916

[19] Nyamathi, A., Salem, B., Reback, C.J., Shoptaw, S., Branson, C.M., Idemundia, F.E., et al. (2013) Correlates of Hepatitis B Virus and HIV Knowledge among Gay and Bisexual Homeless Young Adults in Hollywood. American Journal of Men's Health, 7, 18-26. http://dx.doi.org/10.1177/1557988312456068

[20] Medlow, S., Klineberg, E. and Steinbeck, K. (2014) The Health Diagnoses of Homeless Adolescents: A Systematic Review of the Literature. Journal of Adolescent, 37, 531-542. http://dx.doi.org/10.1016/j.adolescence.2014.04.003

[21] Tevendale, H.D., Lightfoot, M. and Slocum, S.L. (2009) Individual and Environmental Protective Factors for Risky Sexual Behavior among Homeless Youth: An Exploration of Gender Differences. AIDS and Behavior, 13, 154-164. http://dx.doi.org/10.1007/s10461-008-9395-Z

[22] Hudson, A.L., Nyamathi, A. and Sweat, J. (2008) Homeless Youths' Interpersonal Perspectives of Health Care Providers. Issues in Mental Health Nursing, 29, 1277-1289. http://dx.doi.org/10.1080/01612840802498235

[23] Caspi, A. and Bem, D.J. (1990) Personality Continuity and Change across the Life Course. In: Pervin, L.A., Ed., Handbook of Personality: Theory and Research, Kapitel 21, Guilford Press, New York, 549-575.

[24] Moffitt, T.E. (1993) Adolescence-Limited and Life-Course-Persistent Antisocial Behavior: A Developmental Taxonomy. Psychological Review, 100, 674-701. http://dx.doi.org/10.1037/0033-295X.100.4.674

[25] Moffitt, T.E., Caspi, A., Harrington, H. and Milne, B.J. (2002) Males on the Life-Course-Persistent and Adolescence-Limited Antisocial Pathways: Follow-Up at Age 26 Years. Development and Psychopathology, 14, 179-207. http://dx.doi.org/10.1017/S0954579402001104

[26] Laub, J.H. and Sampson, R.J. (2006) Shared Beginnings, Divergent Lives: Delinquent Boys to Age 70. Harvard University Press, Cambridge.

[27] Constantine, R.J., Petrila, J., Andel, R., Givens, E.M., Becker, M., Robst, J., et al. (2010) Arrest Trajectories of Adult Offenders with a Serious Mental Illness. Psychology, Public Policy, and Law, 16, 319-339. http://dx.doi.org/10.1037/a0020852

[28] Greenberg, G. (2008) Jail Incarceration, Homelessness, and Mental Health: A National Study. Psychiatric Services, 59, 170-172. http://dx.doi.org/10.1176/ps.2008.59.2.170

[29] Ferguson, K., Bender, K., Thompson, S., Xie, B. and Pollio, D. (2012) General Strain Predictors of Arrest History among Homeless Youth from Four United States Cities. Journal of Juvenile Justice, 1, 1-19. 
[30] Stein, J.A., Leslie, M.B. and Nyamathi, A. (2002) Relative Contributions of Parent Substance Use and Childhood Maltreatment to Chronic Homelessness, Depression, and Substance Abuse Problems among Homeless Women: Mediating Roles of Self-Esteem and Abuse in Adulthood. Child Abuse \& Neglect, 26, 1011-1027. http://dx.doi.org/10.1016/S0145-2134(02)00382-4

[31] McMorris, B.J., Tyler, K.A., Whitbeck, L.B. and Hoyt, D.R. (2002) Familial and "On-the-Street" Risk Factors Associated with Alcohol Use among Homeless and Runaway Adolescents. Journal of Studies on Alcohol and Drugs, 63, 34-43.

[32] Serbin, L.A., Temcheff, C.E., Cooperman, J.M., Stack, D.M., Ledingham, J. and Schwartzman, A.E. (2011) Predicting Family Poverty and Other Disadvantaged Conditions for Child Rearing from Childhood Aggression and Social withdrawal: A 30-Year Longitudinal Study. International Journal of Behavioral Development, 35, 97-106. http://dx.doi.org/10.1177/0165025410372008

[33] Kazdin, A.E. (1993) Adolescent Mental Health: Prevention and Treatment Programs. American Psychologist, 48, 127-141. http://dx.doi.org/10.1037/0003-066X.48.2.127

[34] Galaif, E.R., Nyamathi, A.M. and Stein, J.A. (1999) Psychosocial Predictors of Current Drug Use, Drug Problems, and Physical Drug Dependence in Homeless Women. Addictive Behaviors, 24, 801-814. http://dx.doi.org/10.1016/S0306-4603(99)00038-6

[35] Benda, B.B. (2005) A Study of Substance Abuse, Traumata, and Social Support Systems among Homeless Veterans. Journal of Human Behavior in the Social Environment, 12, 5982. http://dx.doi.org/10.1300/J137v12n01 04

[36] Buckner, J.C., Bassuk, E.L. and Zima, B.T. (1993) Mental Health Issues Affecting Homeless Women: Implications for Intervention. American Journal of Orthopsychiatry, 63, 385-399. http://dx.doi.org/10.1037/h0079445

[37] Stein, J.A. and Gelberg, L. (1997) Comparability and Representativeness of Clinical Homeless, Community Homeless, and Domiciled Clinic Samples: Physical and Mental Health, Substance Use, and Health Services Utilization. Health Psychology, 16, 155-162. http://dx.doi.org/10.1037/0278-6133.16.2.155

[38] North, C.S. and Smith, E.M. (1993) A Comparison of Homeless Men and Women: Different Populations, Different Needs. Community Mental Health Journal, 29, 423-431. http://dx.doi.org/10.1007/BF00754410

[39] Framework to End Youth Homelessness (2013) A Resource Text for Dialogue and Action. US Interagency Council on Homelessness.

[40] Burt, M.R. (2007) Understanding Homeless Youth: Numbers, Characteristics, Multisystem Involvement, and Intervention Options: Testimony before the US House Committee on Ways and Means. Sect. US House Committee on Ways and Means Subcommittee on Income Security and Family. http://www.urban.org/publications/901087.html

[41] Aceijas, C. (2006) Estimates of Injecting Drug Users at the National and Local Level in Developing and Transitional Countries, and Gender and Age Distribution. Sexually Transmitted Infections, 82, iii10-iii17. http://dx.doi.org/10.1136/sti.2005.019471

[42] Aceijas, C. and Rhodes, T. (2007) Global Estimates of Prevalence of HCV Infection among Injecting Drug Users. International Journal of Drug Policy, 18, 352-358. http://dx.doi.org/10.1016/j.drugpo.2007.04.004

[43] Friedman, S.R., Sandoval, M., Mateu-Gelabert, P., Rossi, D., Gwadz, M., Dombrowski, K., et al. (2013) Theory, Measurement and Hard Times: Some Issues for HIV/AIDS Research. AIDS and Behavior, 17, 1915-1925. http://dx.doi.org/10.1007/s10461-013-0475-3

[44] Lee, B.A., Tyler, K.A. and Wright, J.D. (2010) The New Homelessness Revisited. Annual Review of Sociology, 36, 501-521. http://dx.doi.org/10.1146/annurev-soc-070308-115940 
[45] Marpsat, M. and Razafindratsima, N. (2010) Survey Methods for Hard-to-Reach Populations: Introductions to the Special Issue. Methodological Innovations Online, 5, 3-16.

http://dx.doi.org/10.4256/mio.2010.0014

[46] Hammer, H., Finkelhor, D. and Sedlak, A.J. (2002) NISMART-2 Household Survey Methodology Technical Report. Office of Juvenile Justice and Delinquency Prevention, US Department of Justice, Washington DC.

[47] Berry, B. (2007) A Repeated Observation Approach for Estimating the Street Homeless Population. Evaluation Review, 31, 166-199. http://dx.doi.org/10.1177/0193841X06296947

[48] Auerswald, C.L., Lin, J., Petry, L. and Hyatt, S. (2013) Hidden in Plain Sight: An Assessment of Youth Inclusion in Point-in-Time Counts of California's Unsheltered Homeless Population.

[49] Wright, J.D. and Devine, J.A. (1992) Counting the Homeless The Census Bureau's "S-Night" in Five US Cities. Evaluation Review, 16, 355-364. http://dx.doi.org/10.1177/0193841X9201600401

[50] Cheng, T., Wood, E., Feng, C., Mathias, S., Montaner, J., Kerr, T., et al. (2013) Transitions into and out of Homelessness among Street-Involved Youth in a Canadian Setting. Health Place, 23, 122-127. http://dx.doi.org/10.1016/j.healthplace.2013.06.003

[51] Rashid, S. (2004) Evaluating a Transitional Living Program for Homeless, Former Foster Care Youth. Research on Social Work Practice, 14, 240-248. http://dx.doi.org/10.1177/1049731503257883

[52] Corliss, H.L., Goodenow, C.S., Nichols, L. and Austin, S.B. (2011) High Burden of Homelessness among Sexual-Minority Adolescents: Findings from a Representative Massachusetts High School Sample. American Journal of Public Health, 101, 1683-1689.

http://dx.doi.org/10.2105/AJPH.2011.300155

[53] Kidd, S.A., Karabanow, J., Hughes, J. and Frederick, T. (2013) Brief Report: Youth Pathways out of Homelessness-Preliminary Findings. Journal of Adolescent, 36, 1035-1037. http://dx.doi.org/10.1016/j.adolescence.2013.08.009

[54] Lenz-Rashid, S. (2006) Employment Experiences of Homeless Young Adults: Are they Different for Youth with a History of Foster Care? Children and Youth Services Review, 28, 235-259. http://dx.doi.org/10.1016/j.childyouth.2005.03.006

[55] Nyamathi, A., Hudson, A., Greengold, B., Slagle, A., Marfisee, M., Khalilifard, F., et al. (2010) Correlates of Substance Use Severity among Homeless Youth. Journal of Child and Adolescent Psychiatric Nursing, 23, 214-222. http://dx.doi.org/10.1111/j.1744-6171.2010.00247.x

[56] Nyamathi, A., Hudson, A., Greengold, B. and Leake, B. (2012) Characteristics of Homeless Youth Who Use Cocaine and Methamphetamine. American Journal on Addictions, 21, 243-249. http://dx.doi.org/10.1111/j.1521-0391.2012.00233.x

[57] Feng, C., DeBeck, K., Kerr, T., Mathias, S., Montaner, J. and Wood, E. (2013) Homelessness Independently Predicts Injection Drug Use Initiation among Street-Involved Youth in a Canadian Setting. Journal of Adolescent Health, 52, 499-501. http://dx.doi.org/10.1016/j.jadohealth.2012.07.011

[58] Fielding, K. and Forchuk, C. (2013) Exploring the Factors Associated with Youth Homelessness and Arrests. Journal of Child and Adolescent Psychiatric Nursing, 26, 225-233. http://dx.doi.org/10.1111/jcap.12056

[59] Tyler, K.A. and Melander, L.A. (2013) Child Abuse, Street Victimization, and Substance Use among Homeless Young Adults. Youth \& Society, 47, 502-519.

http://dx.doi.org/10.1177/0044118X12471354 
[60] Collins, J. and Slesnick, N. (2011) Factors Associated with Motivation to Change HIV Risk and Substance Use Behaviors among Homeless Youth. Journal of Social Work Practice in the Addictions, 11, 163-180. http://dx.doi.org/10.1080/1533256X.2011.570219

[61] Rice, E. (2013) Substantial Differences in Risk Behaviors of Homeless Youth in Two Large Networks of Homeless Youth in Los Angeles. 141st American Public Health Association Annual Meeting, Boston, 2-6 November 2013, 1-6.

https://apha.confex.com/apha/141am/webprogramadapt/Paper279743.html

[62] Marshall, B.D.L., Kerr, T., Shoveller, J.A., Patterson, T.L., Buxton, J.A. and Wood, E. (2009) Homelessness and Unstable Housing Associated with an Increased Risk of HIV and STI Transmission among Street-Involved Youth. Health Place, 15, 783-790. http://dx.doi.org/10.1016/j.healthplace.2008.12.005

[63] Whitbeck, L.B., Chen, X., Hoyt, D.R., Tyler, K.A. and Johnson, K.D. (2004) Mental Disorder, Subsistence Strategies, and Victimization among Gay, Lesbian, and Bisexual Homeless and Runaway Adolescents. Journal of Sex Research, 41, 329-342. http://dx.doi.org/10.1080/00224490409552240

[64] Dombrowski, K., Khan, B., McLean, K., Curtis, R., Wendel, T., Misshula, E., et al. (2013) A Reexamination of Connectivity Trends via Exponential Random Graph Modeling in Two IDU Risk Networks. Substance Use \& Misuse, 48, 1485-1497. http://dx.doi.org/10.3109/10826084.2013.796987

[65] Friedman, S.R., Curtis, R., Jose, B., Neaigus, A., Zenilman, J., Culpepper-Morgan, J., et al. (1997) Sex, Drugs, and Infections among Youth. Parenterally and Sexually Transmitted Diseases in a High-Risk Neighborhood. Sex Transm Dis. Sexually Transmitted Infections, 24, 322-326. http://dx.doi.org/10.1097/00007435-199707000-00003

[66] Wenzel, S.L., Leake, B.D. and Gelberg, L. (2001) Risk Factors for Major Violence among Homeless Women. Journal of Interpersonal Violence, 16, 739-752. http://dx.doi.org/10.1177/088626001016008001

[67] Whitbeck, L.B., Hoyt, D.R. and Yoder, K.A. (1999) A Risk-Amplification Model of Victimization and Depressive Symptoms among Runaway and Homeless Adolescents. American Journal of Community Psychology, 27, 273-296. http://dx.doi.org/10.1023/A:1022891802943

[68] Tyler, K.A., Hoyt, D.R., Whitbeck, L.B. and Cauce, A.M. (2001) The Impact of Childhood Sexual Abuse on Later Sexual Victimization among Runaway Youth. Journal of Research on Adolescence, 11, 151-176. http://dx.doi.org/10.1111/1532-7795.00008

[69] Cortes, A., Henry, M., de la Cruz, R. and Brown, S. (2012) The 2012 Point-in-Time Estimates of Homelessness. US Department of Housing and Urban Development, Volume 1 of the 2012 Annual Homeless Assessment Report.

[70] Hopper, K., Shinn, M., Laska, E., Meisner, M. and Wanderling, J. (2008) Estimating Numbers of Unsheltered Homeless People through Plant-Capture and Postcount Survey Methods. American Journal of Public Health, 98, 1438-1442. http://dx.doi.org/10.2105/AJPH.2005.083600

[71] Hall, H.I., Song, R., Gerstle, J.E. and Lee, L.M. (2006) Assessing the Completeness of Reporting of Human Immunodeficiency Virus Diagnoses in 2002-2003: Capture-Recapture Methods. American Journal of Epidemiology, 164, 391-397. http://dx.doi.org/10.1093/aje/kwj216

[72] Hay, G., Gannon, M., MacDougall, J., Eastwood, C., Williams, K. and Millar, T. (2009) Capture-Recapture and Anchored Prevalence Estimation of Injecting Drug Users in England: National and Regional Estimates. Statistical Methods in Medical Research, 18, 323339. http://dx.doi.org/10.1177/0962280208094687 
[73] McDonald, S.A., Hutchinson, S.J., Schnier, C., McLeod, A. and Goldberg, D.J. (2013) Estimating the Number of Injecting Drug Users in Scotland's HCV-Diagnosed Population Using Capture-Recapture Methods. Epidemiology \& Infection, 142, 200-207. http://dx.doi.org/10.1017/s0950268813000617

[74] Fisher, N., Turner, S.W., Pugh, R. and Taylor, C. (1994) Estimating Numbers of Homeless and Homeless Mentally Ill People in North East Westminster by Using Capture-Recapture Analysis. BMJ, 308, 27-30. http://dx.doi.org/10.1136/bmj.308.6920.27

[75] Shaw, I., Bloor, M., Cormack, R. and Williamson, H. (1996) Estimating the Prevalence of Hard-to-Reach Populations: The Illustration of Mark-Recapture Methods in the Study of Homelessness. Social Policy \& Administration, 30, 69-85. http://dx.doi.org/10.1111/j.1467-9515.1996.tb00482.x

[76] Bezerra, K.F., Gurgel, R.Q., Ilozue, C. and Castaneda, D.N. (2011) Estimating the Number of Street Children and Adolescents in Two Cities of Brazil Using Capture-Recapture. Journal of Paediatrics \& Child Health, 47, 524-529. http://dx.doi.org/10.1111/j.1440-1754.2011.02015.x

[77] Simeone, R., Holland, L. and Viveros-Aguilero, R. (2003) Estimating the Size of an Illicit-Drug-Using Population. Statistics in Medicine, 22, 2969-2993.

http://dx.doi.org/10.1002/sim.1528

[78] Berchenko, Y., Rosenblatt, J. and Frost, S.D.W. (2013) Modeling and Analysing Respondent Driven Sampling as a Counting Process. http://arxiv.org/abs/1304.3505

[79] Zhao, Y. (2011) Estimating the Size of an Injecting Drug User Population. World Journal of AIDS, 1, 88-93. http://dx.doi.org/10.4236/wja.2011.13013

[80] Dombrowski, K., Khan, B., Wendel, T., McLean, K., Misshula, E. and Curtis, R. (2012) Estimating the Size of the Methamphetamine-Using Population in New York City Using Network Sampling Techniques. Advances in Applied Sociology, 2, 245-252. http://dx.doi.org/10.4236/aasoci.2012.24032

[81] Bernard, H.R., Hallett, T., Iovita, A., Johnsen, E.C., Lyerla, R., McCarty, C., et al. (2010) Counting Hard-to-Count Populations: The Network Scale-Up Method for Public Health. Sexually Transmitted Infections, 86, ii11-ii15. http://dx.doi.org/10.1136/sti.2010.044446

[82] Ezoe, S., Morooka, T., Noda, T., Sabin, M.L. and Koike, S. (2012) Population Size Estimation of Men Who Have Sex with Men through the Network Scale-Up Method in Japan. PLOS ONE, 7, e31184. http://dx.doi.org/10.1371/journal.pone.0031184

[83] Guo, W., Bao, S., Lin W., Wu, G., Zhang, W., Hladik, W., et al. (2013) Estimating the Size of HIV Key Affected Populations in Chongqing, China, Using the Network Scale-Up Method. PLOS ONE, 8, e71796. http://dx.doi.org/10.1371/journal.pone.0071796

[84] Habecker, P., Dombrowski, K. and Khan, B. (2015) Improving the Network Scale-Up Estimator, Incorporating Means of Sums, Recursive Back Estimation, and Sampling Weights. PLoS ONE, 10, e0143406. http://dx.doi.org/10.1371/journal.pone.0143406

[85] Salganik, M.J., Fazito, D., Bertoni, N., Abdo, A.H., Mello, M.B. and Bastos, F.I. (2011) Assessing Network Scale-Up Estimates for Groups Most at Risk of HIV/AIDS: Evidence from a Multiple-Method Study of Heavy Drug Users in Curitiba, Brazil. American Journal of Epidemiology, 174, 1190-1196. http://dx.doi.org/10.1093/aje/kwr246

[86] Heckathorn, D.D. (2002) Respondent-Driven Sampling II: Deriving Valid Population Estimates from Chain-Referral Samples of Hidden Populations. Social Problems, 49, 11-34. http://dx.doi.org/10.1525/sp.2002.49.1.11

[87] Heckathorn, D.D. (2007) Extensions of Respondent-Driven Sampling: Analyzing Continuous Variables and Controlling for Differential Recruitment. Sociological Methodology, 37, 151-207. http://dx.doi.org/10.1111/j.1467-9531.2007.00188.x 
[88] Salganik, M.J. and Heckathorn, D.D. (2004) Sampling and Estimation in Hidden Populations Using Respondent-Driven Sampling. Sociological Methodology, 34, 193-239. http://dx.doi.org/10.1111/j.0081-1750.2004.00152.x

[89] Dombrowski, K., Khan, B., Moses, J., Channell, E. and Misshula, E. (2013) Assessing Respondent Driven Sampling for Network Studies in Ethnographic Contexts. Advances in Anthropology, 3, 1-9. http://dx.doi.org/10.4236/aa.2013.31001

[90] Curtis, R., Terry, K., Dank, M., Dombrowski, K. and Khan, B. (2008) The Commercial Sexual Exploitation of Children in New York City, Volume 1: The CSEC Population in New York City: Size, Characteristics, and Needs. NCJ Publication No. 225083. Bureau of Justice Statistics, Washington DC.

[91] Wendel, T., Khan, B., Dombrowski, K., Curtis, R., McLean, K., Misshula, E., et al. (2011) Dynamics of Methamphetamine Markets in New York City: Final Technical Report to the National Institute of Justice. A Report to the National Institute of Justice, Document No. 236122.

[92] Ennett, S.T., Bailey, S.L. and Federman, E.B. (1999) Social Network Characteristics Associated with Risky Behaviors among Runaway and Homeless Youth. Journal of Health and Social Behavior, 40, 63-78. http://dx.doi.org/10.2307/2676379

[93] Rice, E., Milburn, N.G. and Rotheram-Borus, M.J. (2007) Pro-Social and Problematic Social Network Influences on HIV/AIDS Risk Behaviours among Newly Homeless Youth in Los Angeles. AIDS Care, 19, 697-704. http://dx.doi.org/10.1080/09540120601087038

[94] Rice, E., Milburn, N.G., Rotheram-Borus, M.J., Mallett, S. and Rosenthal, D. (2005) The Effects of Peer Group Network Properties on Drug Use among Homeless Youth. American Behavioral Scientist, 48, 1102-1123. http://dx.doi.org/10.1177/0002764204274194

[95] Bousman, C.A., Blumberg, E.J., Shillington, A.M., Hovell, M.F., Ji, M., Lehman, S., et al. (2005) Predictors of Substance Use among Homeless Youth in San Diego. Addictive Behaviors, 30, 1100-1110. http://dx.doi.org/10.1016/j.addbeh.2004.10.006

[96] Kipke, M.D., Montgomery, S.B., Simon, T.R., Unger, J.B. and Johnson, C.J. (1997) Homeless Youth: Drug Use Patterns and HIV Risk Profiles According to Peer Group Affiliation. AIDS and Behavior, 1, 247-259. http://dx.doi.org/10.1023/A:1026279402791

[97] Ferguson, K.M., Bender, K., Thompson, S., Xie, B. and Pollio, D. (2011) Correlates of Street-Survival Behaviors in Homeless Young Adults in Four US Cities. American Journal of Orthopsychiatry, 81, 401-409. http://dx.doi.org/10.1111/j.1939-0025.2011.01108.x

[98] Tyler, K.A. (2008) Social Network Characteristics and Risky Sexual and Drug Related Behaviors among Homeless Young Adults. Social Science Research, 37, 673-685. http://dx.doi.org/10.1016/j.ssresearch.2007.09.004

[99] Um, M.Y. (2014) Influence of "Traveling" Youth and Substance Use Behaviors in the Social Networks of Homeless Youth. 142nd American Public Health Association Annual Meeting and Exposition, New Orleans, 15-19 November 2014, 1-7. https://apha.confex.com/apha/142am/webprogram/Paper307761.html

[100] Rice, E., Stein, J.A. and Milburn, N. (2008) Countervailing Social Network Influences on Problem Behaviors among Homeless Youth. Journal of Adolescent, 31, 625-639. http://dx.doi.org/10.1016/j.adolescence.2007.10.008

[101] Martino, S.C., Tucker, J.S., Ryan, G., Wenzel, S.L., Golinelli, D. and Munjas, B. (2011) Increased Substance Use and Risky Sexual Behavior among Migratory Homeless Youth: Exploring the Role of Social Network Composition. Journal of Youth and Adolescence, 40, 1634-1648. http://dx.doi.org/10.1007/s10964-011-9646-6 
[102] Thompson, S.J., Rew, L., Barczyk, A., McCoy, P. and Mi-Sedhi, A. (2009) Social Estrangement: Factors Associated with Alcohol or Drug Dependency among Homeless, StreetInvolved Young Adults. Journal of Drug Issues, 39, 905-929.

http://dx.doi.org/10.1177/002204260903900407

[103] Lyons, T., Kerr, T., Duff, P., Feng, C. and Shannon, K. (2013) Youth, Violence and Non-Injection Drug Use: Nexus of Vulnerabilities among Lesbian and Bisexual Sex Workers. AIDS Care, 26, 1090-1094. http://dx.doi.org/10.1080/09540121.2013.869542

[104] Warf, C.W., Clark, L.F., Desai, M., Rabinovitz, S.J., Agahi, G., Calvo, R., et al. (2013) Coming of Age on the Streets: Survival Sex among Homeless Young Women in Hollywood. Journal of Adolescent, 36, 1205-1213. http://dx.doi.org/10.1016/j.adolescence.2013.08.013

[105] Weber, M.A.E., Boivin, D.J.-F., Blais, D.L., Haley, D.N. and Roy, D.É. (2004) Predictors of Initiation into Prostitution among Female Street Youths. Journal of Urban Health, 81, 584595. http://dx.doi.org/10.1093/jurban/jth142

[106] Rudolph, A.E., Linton, S., Dyer, T.P. and Latkin, C. (2013) Individual, Network, and Neighborhood Correlates of Exchange Sex among Female Non-Injection Drug Users in Baltimore, MD (2005-2007). AIDS and Behavior, 17, 598-611. http://dx.doi.org/10.1007/s10461-012-0305-Z

[107] Friedman, S.R., Curtis, R., Neaigus, A., Jose, B. and Jarlais, D.C.D. (2010) Social Networks, Drug Injectors' Lives, and HIV/AIDS. Springer, Berlin.

[108] Falci, C.D., Whitbeck, L.B., Hoyt, D.R. and Rose, T. (2011) Predictors of Change in Self-Reported Social Networks among Homeless Young People. Journal of Research on Adolescence, 21, 827-841. http://dx.doi.org/10.1111/j.1532-7795.2011.00741.x

[109] De la Haye, K., Green, H.D., Kennedy, D.P., Zhou, A., Golinelli, D., Wenzel, S.L., et al. (2012) Who Is Supporting Homeless Youth? Predictors of Support in Personal Networks. Journal of Research on Adolescence, 22, 604-616. http://dx.doi.org/10.1111/j.1532-7795.2012.00806.x

[110] Chew, N.R.A., Muth, S.Q. and Auerswald, C.L. (2013) Impact of Social Network Characteristics on Shelter Use among Street Youth in San Francisco. Journal of Adolescent Health, 53, 381-386. http://dx.doi.org/10.1016/j.jadohealth.2013.04.018

[111] Rice, E., Milburn, N.G. and Monro, W. (2011) Social Networking Technology, Social Network Composition, and Reductions in Substance Use among Homeless Adolescents. Prevention sciences, 12, 80-88. http://dx.doi.org/10.1007/s11121-010-0191-4

[112] Rice, E. and Rhoades, H. (2013) How Should Network-Based Prevention for Homeless Youth Be Implemented? Addiction, 108, 1625-1626. http://dx.doi.org/10.1111/add.12255

[113] Surratt, H.L. and Kurtz, S.P. (2012) Foster Care History and HIV Infection among Drug-Using African American Female Sex Workers. AIDS and Behavior, 16, 982-989. http://dx.doi.org/10.1007/s10461-011-0008-x

[114] Thompson, R.G. and Auslander, W.F. (2011) Substance Use and Mental Health Problems as Predictors of HIV Sexual Risk Behaviors among Adolescents in Foster Care. Health \& Social Work, 36, 33-43. http://dx.doi.org/10.1093/hsw/36.1.33

[115] Banyard, V.L. and Graham-Bermann, S.A. (1998) Surviving Poverty: Stress and Coping in the Lives of Housed and Homeless Mothers. American Journal of Orthopsychiatry, 68, 479489. http://dx.doi.org/10.1037/h0080357

[116] Tucker, J.S., D’Amico, E.J., Wenzel, S.L., Golinelli, D., Elliott, M.N. and Williamson, S. (2005) A Prospective Study of Risk and Protective Factors for Substance Use among Impoverished Women Living in Temporary Shelter Settings in Los Angeles County. Drug and Alcohol Dependence, 80, 35-43. http://dx.doi.org/10.1016/j.drugalcdep.2005.03.008 
[117] Kushel, M.B., Evans, J.L., Perry, S., Robertson, M.J. and Moss, A.R. (2003) No Door to Lock: Victimization among Homeless and Marginally Housed Persons. Archives of Internal Medicine, 163, 2492-2499. http://dx.doi.org/10.1001/archinte.163.20.2492

[118] Hoffman, D. and Rosenheck, R. (2001) Homeless Mothers with Severe Mental Illnesses and Their Children: Predictors of Family Reunification. Psychiatric Rehabilitation, 25, 163-169. http://dx.doi.org/10.1037/h0095029

[119] Smith, E.M. and North, C. (1994) Not All Homeless Women Are Alike: Effects of Motherhood and the Presence of Children. Community Mental Health Journal, 30, 601-610. http://dx.doi.org/10.1007/BF02188596

[120] Gould, M. and Ardinger, R. (1988) Self Advocacy: A Community Solution to Access Discrimination and Service Problems Encountered by the "Homeless Disabled." Nonprofit and Voluntary Sector Quarterly, 17, 46-53. http://dx.doi.org/10.1177/089976408801700107

[121] Bassuk, E.L. (1993) Social and Economic Hardships of Homeless and Other Poor Women. American Journal of Orthopsychiatry, 63, 340-347. http://dx.doi.org/10.1037/h0079443

[122] Lloyd, D.A. and Turner, R.J. (2008) Cumulative Lifetime Adversities and Alcohol Dependence in Adolescence and Young Adulthood. Drug and Alcohol Dependence, 93, 217-226. http://dx.doi.org/10.1016/j.drugalcdep.2007.09.012

[123] Turner, R.J. and Lloyd, D.A. (2003) Cumulative Adversity and Drug Dependence in Young Adults: Racial/Ethnic Contrasts. Addiction, 98, 305-315. http://dx.doi.org/10.1046/j.1360-0443.2003.00312.x

[124] Turner, H.A. and Turner, R.J. (2005) Understanding Variations in Exposure to Social Stress. Health, 9, 209-240. http://dx.doi.org/10.1177/1363459305050586

[125] Tucker, J.S., Wenzel, S.L., Golinelli, D., Zhou, A. and Green, H.D. (2011) Predictors of Substance Abuse Treatment Need and Receipt among Homeless Women. Journal of Substance Abuse Treatment, 40, 287-294. http://dx.doi.org/10.1016/j.jsat.2010.11.006

[126] Wenzel, S.L., Green, H.D., Tucker, J.S., Golinelli, D., Kennedy, D.P., Ryan, G., et al. (2009) The Social Context of Homeless Women's Alcohol and Drug Use. Drug and Alcohol Dependence, 105, 16-23. http://dx.doi.org/10.1016/j.drugalcdep.2009.05.026

[127] Daley, S.E., Hammen, C., Burge, D., Davila, J., Paley, B., Lindberg, N., et al. (1997) Predictors of the Generation of Episodic Stress: A Longitudinal Study of Late Adolescent Women. Journal of Abnormal Psychology, 106, 251-259. http://dx.doi.org/10.1037/0021-843X.106.2.251

[128] Thoits, P.A. (2006) Personal Agency in the Stress Process. Journal of Health and Social Behavior, 47, 309-323. http://dx.doi.org/10.1177/002214650604700401

[129] Pearlin, L.I. (1989) The Sociological Study of Stress. Journal of Health and Social Behavior, 30, 241-256. http://dx.doi.org/10.2307/2136956

[130] Pearlin, L.I., Schieman, S., Fazio, E.M. and Meersman, S.C. (2005) Stress, Health, and the Life Course: Some Conceptual Perspectives. Journal of Health and Social Behavior, 46, 205219. http://dx.doi.org/10.1177/002214650504600206

[131] Wenzel, S.L., Koegel, P. and Gelberg, L. (2000) Antecedents of Physical and Sexual Victimization among Homeless Women: A Comparison to Homeless Men. American Journal of Community Psychology, 28, 367-390. http://dx.doi.org/10.1023/A:1005157405618

[132] Keyes, K.M., Hatzenbuehler, M.L. and Hasin, D.S. (2011) Stressful Life Experiences, Alcohol Consumption, and Alcohol Use Disorders: The Epidemiologic Evidence for Four Main Types of Stressors. Psychopharmacology, 218, 1-17.

http://dx.doi.org/10.1007/s00213-011-2236-1 
[133] Bassuk, E.L. and Rosenberg, L. (1988) Why Does Family Homelessness Occur? A CaseControl Study. American Journal of Public Health, 78, 783-788.

http://dx.doi.org/10.2105/AJPH.78.7.783

[134] Butterfield, M.I., Panzer, P.G. and Forneris, C.A. (1999) Victimization of Women and Its Impact on Assessment and Treatment in the Psychiatric Emergency Setting. Psychiatric Clinics of North America, 22, 875-896. http://dx.doi.org/10.1016/S0193-953X(05)70131-3

[135] Duncan, R.D., Saunders, B.E., Kilpatrick, D.G., Hanson, R.F. and Resnick, H.S. (1996) Childhood Physical Assault as a Risk Factor for PTSD, Depression, and Substance Abuse: Findings from a National Survey. American Journal of Orthopsychiatry, 66, 437-448. http://dx.doi.org/10.1037/h0080194

[136] North, C.S., Smith, E.M. and Spitznagel, E.L. (1994) Violence and the Homeless: An Epidemiologic Study of Victimization and Aggression. Journal of Traumatic Stress, 7, 95-110. http://dx.doi.org/10.1002/jts.2490070110

[137] Bassuk, E.L., Melnick, S. and Browne, A. (1998) Responding to the Needs of Low-Income and Homeless Women Who Are Survivors of Family Violence. American Medical Women's Association, 53, 57-64.

[138] Golinelli, D., Longshore, D. and Wenzel, S.L. (2009) Substance Use and Intimate Partner Violence, Clarifying the Relevance of Women's Use and Partners' Use. Journal of Behavioral Health Services and Research, 36, 199-211. http://dx.doi.org/10.1007/s11414-008-9114-6

[139] Tyler, K.A., Hagewen, K.J. and Melander, L.A. (2011) Risk Factors for Running away among a General Population Sample of Males and Females. Youth \& Society, 43, 583-608. http://dx.doi.org/10.1177/0044118X11400023

[140] Pearlin, L.I., Aneshensel, C.S. and Leblanc, A.J. (1997) The Forms and Mechanisms of Stress Proliferation: The Case of AIDS Caregivers. Journal of Health and Social Behavior, 38, 223-236. http://dx.doi.org/10.2307/2955368

[141] Whitbeck, L.B., Hoyt, D.R., Johnson, K.D. and Chen, X. (2007) Victimization and Posttraumatic Stress Disorder among Runaway and Homeless Adolescents. iolence and Victims, 22, 721-734. http://dx.doi.org/10.1891/088667007782793165

[142] The US Department of Housing and Urban Development (2012) The 2011 Annual Homeless Assessment Report to Congress. https://www.hudexchange.info/resources/documents/2011AHAR FinalReport.pdf

[143] Coalition for the Homeless (2009) Foreclosure to Homelessness: The Forgotten Victims of the Subprime Crisis. Coalition for the Homeless. http://www.nationalhomeless.org/factsheets/foreclosure.pdf

[144] Goodman, P.S. (2009) Foreclosures Force Ex-Homeowners to Turn to Shelters. NY Times. http://www.nytimes.com/2009/10/19/business/economy/19foreclosed.html?emc=eta1\&pag ewanted $=$ print $\% 20(1 \% 20$ of\%206)\%20[10/19/2009\%209:24:46\%20AM]\& r $=0$

[145] Cagney, K.A., Browning, C.R., Iveniuk, J. and English, N. (2014) The Onset of Depression During the Great Recession: Foreclosure and Older Adult Mental Health. American Journal of Public Health, 104, 498-505. http://dx.doi.org/10.2105/AJPH.2013.301566

[146] Cannuscio, C.C., Alley, D.E., Pagán, J.A., Soldo, B., Krasny, S., Shardell, M., et al. (2012) Housing Strain, Mortgage Foreclosure, and Health. Nursing Outlook, 60, 134-142. http://dx.doi.org/10.1016/j.outlook.2011.08.004

[147] Houle, J.N. (2014) Mental Health in the Foreclosure Crisis. Social Science \& Medicine, 118, 1-8. http://dx.doi.org/10.1016/j.socscimed.2014.07.054

[148] Barcus, H.R. and Simmons, L. (2013) Ethnic Restructuring in Rural America: Migration and the Changing Faces of Rural Communities in the Great Plains. The Professional Geo- 
grapher, 65, 130-152. http://dx.doi.org/10.1080/00330124.2012.658713

[149] Xu, Z. (2014) Spatial and Longitudinal Patterns in County Age-Specific Net Migration in the United States 1950-2010. The Professional Geographer, 66, 641-652. http://dx.doi.org/10.1080/00330124.2013.868690

[150] Stull, D.D., Broadway, M.J., Griffith, D., et al. (1995) Any Way You Cut It: Meat Processing and Small-Town America. University Press of Kansas. Annals of Iowa, 56, 179-180.

[151] Stull, D. and Broadway, M. (2012) Slaughterhouse Blues: The Meat and Poultry Industry in North America. Cengage Learning, Boston.

[152] Marrow, H. (2011) New Destination Dreaming: Immigration, Race, and Legal Status in the Rural American South. Stanford University Press, Redwood City.

[153] Shepard, R. (2014) The Role of Gender in Rural Population Decline in Kansas and Nebraska, 1990-2010. Great Plains Research, 24, 1-12. http://dx.doi.org/10.1353/gpr.2014.0010

[154] DE Wit, C.W. (2001) Women's Sense of Place on the American High Plains. Great Plains Quarterly, 21, 29-44.

[155] Felsenstein, D. and Persky, J. (2011) Gender and Job Chains in Local Economic Development. Economic Development Quarterly, 25, 172-181. http://dx.doi.org/10.1177/0891242410393953

[156] Reichert, C., Cromartie, J.B. and Arthun, R.O. (2014) Impacts of Return Migration on Rural US Communities. Rural Sociology, 79, 200-226. http://dx.doi.org/10.1111/ruso.12024

[157] Von Reichert, C., Cromartie, J.B. and Arthun, R.O. (2011) Returning Home and Making a Living, Employment Strategies of Returning Migrants to Rural US Communities. Journal of Rural and Community Development, 6, 35-52.

[158] Homan, G., Hedrick, J., Dick, J., Light, M. and Ramsey, D. (2014) How Young Adults Perceive Their Rural Ohio Communities. Journal of Rural and Community Development, 9, 1-13.

[159] Carnevale, A.P. and Smith, N. (2011) The Midwest Challenge: Matching Jobs with Education in the Post-Recession Economy. Georgetown University Center on Education and the Workforce. http://eric.ed.gov/?id=ED525299

[160] Mammen, S., Dolan, E. and Seiling, S.B. (2014) Explaining the Poverty Dynamics of Rural Families Using an Economic Well-Being Continuum. Journal of Family and Economic Issues, 36, 434-450. http://dx.doi.org/10.1007/s10834-014-9405-4

[161] Mishra, B., Gautam, S. and Poudel, K.L. (2014) An Analysis of Distribution and Concentration of Poverty in Missouri. Agrarian Frontiers, 2, 2-20.

[162] Garrett-Peters, P. and Mills-Koonce, R. (2012) Employment Instability and Food Insecurity of Rural North Carolinians during the Recession. http://srdc.msstate.edu/ridge/projects/previous/demarco 2011.pdf

[163] Teruya, C., Longshore, D., Andersen, R.M., Arangua, L., Nyamathi, A., Leake, B., et al. (2010) Health and Health Care Disparities among Homeless Women. Women Health, 50, 719-736. http://dx.doi.org/10.1080/03630242.2010.532754

[164] Wilson, M. (2005) Health-Promoting Behaviors of Sheltered Homeless Women. Family \& Community Health, 28, 51-63. http://dx.doi.org/10.1097/00003727-200501000-00008

[165] Notaro, S.J., Khan, M., Kim, C., Nasaruddin, M. and Desai, K. (2013) Analysis of the Health Status of the Homeless Clients Utilizing a Free Clinic. Journal of Community Health, 38, 172-177. http://dx.doi.org/10.1007/s10900-012-9598-0

[166] Wood, D., Valdez, R.B., Hayashi, T. and Shen, A. (1990) Homeless and Housed Families in Los Angeles: A Study Comparing Demographic, Economic, and Family Function Characte- 
ristics. American Journal of Public Health, 80, 1049-1052.

http://dx.doi.org/10.2105/AJPH.80.9.1049

[167] Zugazaga, C. (2004) Stressful Life Event Experiences of Homeless Adults: A Comparison of Single Men, Single Women, and Women with Children. Journal of Community Psychology, 32, 643-654. http://dx.doi.org/10.1002/jcop.20025

[168] Jasinski, D.R., González, M.A., Peoples, K.A. and Rubin, J. (2007) Human Pharmacology and Abuse Potential of Transdermal Methylphenidate in Adults. American Psychiatric Association's 160 th Annual Meeting, San Diego, 19-24 May 2007, 1-13.

[169] Grant, B.F., Dawson, D.A., Stinson, F.S., Chou, S.P., Dufour, M.C. and Pickering, R.P. (2004) The 12-Month Prevalence and Trends in DSM-IV Alcohol Abuse and Dependence: United States, 1991-1992 and 2001-2002. Drug and Alcohol Dependence, 74, 223-234. http://dx.doi.org/10.1016/j.drugalcdep.2004.02.004

[170] Baker, S.G. (1994) Gender, Ethnicity, and Homelessness: Accounting for Demographic Diversity on the Streets. American Behavioral Scientist, 37, 476-504. http://dx.doi.org/10.1177/0002764294037004005

[171] Popielarz, P.A. and Neal, Z.P. (2007) The Niche as a Theoretical Tool. Annual Review of Sociology, 33, 65-84. http://dx.doi.org/10.1146/annurev.soc.32.061604.123118

[172] McPherson, M. (1983) An Ecology of Affiliation. The American Sociological Review, 48, 519-532. http://dx.doi.org/10.2307/2117719

[173] Ning, C.R. and Jackson, A.L. (2013) The Social Ecology of Public Space: Active Streets and Violent Crime in Urban Neighborhoods. Criminology, 51, 1009-1043. http://dx.doi.org/10.1111/1745-9125.12026

[174] Ensel, W.M. and Lin, N. (1991) The Life Stress Paradigm and Psychological Distress. Journal of Health and Social Behavior, 32, 321-341. http://dx.doi.org/10.2307/2137101

[175] Moody, J. (2002) The Importance of Relationship Timing for Diffusion. Social Forces, 81, 25-56. http://dx.doi.org/10.1353/sof.2002.0056

[176] Moody, J., McFarland, D. and Bender-deMoll, S. (2005) Dynamic Network Visualization1. American Journal of Sociology, 110, 1206-1241. http://dx.doi.org/10.1086/421509

[177] Kossinets, G. (2006) Effects of Missing Data in Social Networks. Social Networks, 28, 247 268. http://dx.doi.org/10.1016/j.socnet.2005.07.002

[178] George, L.K. (2014) Taking Time Seriously: A Call to Action in Mental Health Research. Journal of Health and Social Behavior, 55, 251-264. http://dx.doi.org/10.1177/0022146514542434 
Submit or recommend next manuscript to SCIRP and we will provide best service for you:

Accepting pre-submission inquiries through Email, Facebook, LinkedIn, Twitter, etc. A wide selection of journals (inclusive of 9 subjects, more than 200 journals)

Providing 24-hour high-quality service

User-friendly online submission system

Fair and swift peer-review system

Efficient typesetting and proofreading procedure

Display of the result of downloads and visits, as well as the number of cited articles

Maximum dissemination of your research work

Submit your manuscript at: http://papersubmission.scirp.org/ 